\title{
20-Hydroxyeicosa-Tetraenoic Acid (20 HETE) Activates Protein Kinase C Role in Regulation of Rat Renal $\mathrm{Na}^{+}, \mathrm{K}^{+}$-ATPase
}

\author{
Susana Nowicki, ${ }^{\star}$ Shan Lin Chen, ${ }^{\star}$ Oleg Aizman, ${ }^{*}$ Xian Jun Cheng, ${ }^{\star}$ Dailin Li, ${ }^{\star}$ Cristina Nowicki, ${ }^{\S}$ Angus Nairn, ${ }^{\ddagger}$ \\ Paul Greengard, ${ }^{\ddagger}$ and Anita Aperia* \\ *Department of Woman and Child Health, Karolinska Institute, Stockholm, Sweden; ${ }^{\ddagger}$ Laboratory of Molecular and Cellular \\ Neuroscience, The Rockefeller University, New York 10021; and ${ }^{\S} I Q U I F I B$ (UBA-CONICET), Facultad de Farmacia y Bioquimica, \\ Universidad de Buenos Aires, Buenos Aires, Argentina
}

\begin{abstract}
It is well documented that the activity of $\mathrm{Na}^{+}, \mathrm{K}^{+}$-ATPase can be inhibited by the arachidonic acid metabolite, 20hydroxyeicosa-tetraenoic acid (20 HETE). Evidence is presented here that this effect is mediated by protein kinase $\mathrm{C}$ (PKC). PKC inhibitors abolished 20 HETE inhibition of rat $\mathrm{Na}^{+}, \mathrm{K}^{+}$-ATPase in renal tubular cells. 20 HETE caused translocation of PKC $\alpha$ from cytoplasm to membrane in COS cells. It also inhibited $\mathrm{Na}^{+}, \mathrm{K}^{+}$-ATPase activity in COS cells transfected with rat wild-type renal $\mathrm{Na}^{+}, \mathrm{K}^{+}$-ATPase $\alpha_{1}$ subunit, but not in cells transfected with $\mathrm{Na}^{+}, \mathrm{K}^{+}$-ATPase $\alpha 1$, where the PKC phosphorylation site, serine 23, had been mutated to alanine. PKC-induced phosphorylation of rat renal $\mathrm{Na}^{+}, \mathrm{K}^{+}$-ATPase, as well as of histone was strongly enhanced by 20 HETE at the physiologic calcium concentration of $1.3 \mu \mathrm{M}$, but not at the calcium concentration of 200 $\mu \mathrm{M}$. The results indicate that phospholipase $\mathrm{A}_{2}$-arachidonic acid-20 HETE pathway can exert important biological effects via activation of PKC and that this effect may occur in the absence of a rise in intracellular calcium. (J. Clin. Invest. 1997. 99:1224-1230.) Key words: cytochrome P-450 • phosphorylation - protein kinase $\mathrm{C}$ inhibitors $\cdot$ protein kinase $\mathrm{C}$ translocation $\cdot$ proximal tubules
\end{abstract}

\section{Introduction}

Arachidonic acid is released from cell membranes in response to receptor-dependent activation of phospholipase $\mathrm{A}_{2}\left(\mathrm{PLA}_{2}\right)^{1}$

Portions of this work have been presented at the 28th Annual Meeting of the American Society of Nephrology in San Diego, CA on 5 November 1995. Portions of this work have appeared in abstract form (1995. J. Am. Soc. Nephrol. 6:S536).

Address correspondence to Anita Aperia, Department of Woman and Child Health, Pediatric Unit, St. Göran's Children's Hospital, S-11281 Stockholm, Sweden. Phone: +46 8672 2222; FAX: +468672 1941; E-mail: aniap@child.ks.se

Received for publication 2 October 1996 and accepted in revised form 2 January 1997.

1. Abbreviations used in this paper: 20 HETE, 20-hydroxyeicosa-tetraenoic acid; OAG, 1-oleoyl-2-acetoyl-sn-glycerol; P-450, cytochrome $\mathrm{P}-450$ monooxygenase; PDBu, phorbol 12,13-dibutyrate; Pi, inorganic phosphate; PKC, calcium- and phospholipid-dependent protein kinase; $\mathrm{PLA}_{2}$, phospholipase $\mathrm{A}_{2}$.

J. Clin. Invest.

(C) The American Society for Clinical Investigation, Inc. 0021-9738/97/03/1224/07 \$2.00

Volume 99, Number 6, March 1997, 1224-1230 and can be metabolized via at least three different pathways: the cyclooxygenase, the lipoxygenase and the cytochrome P-450 monooxygenase pathways (P-450) (for review, see references $1,2)$. The P-450 metabolites of arachidonic acid appear to be of special importance for the regulation of ion pumps and ion channels (3-5). The $\omega$-hydroxylation product 20-hydroxyeicosa-tetraenoic acid (20-HETE) constitutes one of the major arachidonic acid metabolites in the kidney. This metabolite, which is mainly produced in the proximal tubular cells, has been shown to inhibit the activity of $\mathrm{Na}^{+}, \mathrm{K}^{+}$-ATPase, the electrogenic ion pump that catalyzes the transcellular transport of sodium in each tubular segment (5-7). The molecular mechanisms responsible for this effect are unknown. $\mathrm{Na}^{+}, \mathrm{K}^{+}$-ATPase is a substrate for protein kinase $\mathrm{C}(\mathrm{PKC})$ and phosphorylation of $\mathrm{Na}^{+}, \mathrm{K}^{+}$-ATPase by PKC has been shown to cause inhibition of the activity of the pump (8-10).

In the present study, we have examined the possibility that 20 HETE may regulate rat renal $\mathrm{Na}^{+}, \mathrm{K}^{+}$-ATPase via a pathway that involves $\mathrm{PKC}$ activation. In support of this possibility, we found that 20 HETE-induced inhibition of rat renal $\mathrm{Na}^{+}, \mathrm{K}^{+}$-ATPase in intact cells was abolished not only by specific $\mathrm{PKC}$ inhibitors, but also by mutation of the $\mathrm{PKC}$ regulatory site, which for the rat $\mathrm{Na}^{+}, \mathrm{K}^{+}$-ATPase $\alpha 1$ subunit is Ser 23 of the $\alpha$ subunit. Furthermore, it was found that phosphorylation of rat renal $\mathrm{Na}^{+}, \mathrm{K}^{+}$-ATPase $\alpha$ subunit, as well as of histone, was significantly enhanced by $20 \mathrm{HETE}$. The results indicate that $20 \mathrm{HETE}$, one of the major renal $\mathrm{PLA}_{2}$ pathway metabolites, can, at physiological calcium ion concentrations, activate $\mathrm{PKC}$ and via phosphorylation reaction(s) inhibit the activity of $\mathrm{Na}^{+}, \mathrm{K}^{+}$-ATPase.

\section{Methods}

Microdissection of single tubular segments and determination of $\mathrm{Na}^{+}, \mathrm{K}^{+}$-ATPase activity. Kidney proximal tubule segments (length $0.5-1 \mathrm{~mm}$ ) were dissected from collagenase $(0.05 \%)$-perfused Sprague Dawley rats (B\&K Universal, Sollentuna, Sweden). After dissection, $\mathrm{Na}^{+}, \mathrm{K}^{+}$ATPase activity was determined in each tubule segment after incubation for $30 \mathrm{~min}$ at room temperature in oxygenated modified Hank's solution (MHS) containing (mM): $137 \mathrm{NaCl}, 5 \mathrm{KCl}, 0.8$ $\mathrm{MgSO}_{4}, 0.33 \mathrm{Na}_{2} \mathrm{HPO}_{4}, 0.44 \mathrm{KH}_{2} \mathrm{PO}_{4}, 0.25 \mathrm{CaCl}_{2}, 1 \mathrm{MgCl}_{2}, 10$ TrisHCl. $10^{-3} \mathrm{M}$ butyrate was added to the solution to optimize mitochondrial respiration. Tubules were incubated in MHS alone (control tubules) or MHS plus drugs (experimental). The following drugs were used: 20 HETE $\left(10^{-6} \mathrm{M}\right)$; GF109203x $\left(10^{-6} \mathrm{M}\right)$; RO318220 $\left(10^{-7} \mathrm{M}\right) . \mathrm{Na}^{+}, \mathrm{K}^{+}$-ATPase activity was measured as described (8).

Purification of rat renal $\mathrm{Na}^{+}, \mathrm{K}^{+}$-ATPase. $\mathrm{Na}^{+}, \mathrm{K}^{+}$-ATPase was purified from rat renal cortex as described (11). The preparation was analyzed by SDS-polyacrylamide gel electrophoresis, stained with Coomassie brillant blue. Densitometric analysis of the stained gels indicated that $\mathrm{Na}^{+}, \mathrm{K}^{+}$-ATPase $\alpha$ subunit was $\sim 55 \%$ of total protein. 
The activity of the purified enzyme was measured (as described in reference 12) as the rate of formation of inorganic ${ }^{32} \mathrm{P}$ from $\left[\gamma-{ }^{32} \mathrm{P}\right] \mathrm{ATP}$ in the absence and presence of ouabain.

Phosphorylation of purified $\mathrm{Na}^{+}, \mathrm{K}^{+}$-ATPase by PKC. Assays were carried out at $24^{\circ} \mathrm{C}$ in a reaction volume of $20 \mu \mathrm{l}$ containing: $50 \mathrm{mM}$ Hepes (pH 7.5), $10 \mathrm{mM} \mathrm{MgCl} 2,1 \mathrm{mM}$ EGTA, $10 \mathrm{nM}$ PKC, and $1 \mu \mathrm{g}$ of purified $\mathrm{Na}^{+}, \mathrm{K}^{+}$-ATPase. Calcium and 20 HETE concentrations are described below for each experiment. Reactions were initiated by the addition of ATP (final concentration $0.1 \mathrm{mM}$ ), with a trace of $\left[\gamma^{-}{ }^{32} \mathrm{P}\right]$ ATP $(2,000-3,000 \mathrm{cpm} / \mathrm{pmol})$. Unless specified, the incubation time was $2 \mathrm{~min}$. Reactions were stopped by the addition of SDS sample buffer. Samples were analyzed by electrophoresis using a $7.5 \%$ SDS-PAGE. Gels were stained with Coomassie brillant blue, destained, dried, and analyzed by radioautography or phosphorimaging. In accordance with what had been found in previous studies (13), phosphate was only incorporated into the catalytic $\alpha$ subunit of $\mathrm{Na}^{+}, \mathrm{K}^{+}$-ATPase. Radioactivity was quantified by scanning the phosphorimages using a Molecular Analyst program (Bio-Rad Laboratories, Hercules, CA).

The stoichiometry of the phosphorylation reaction was quantified by measuring the amount of protein in the $\alpha$ subunit of $\mathrm{Na}^{+}, \mathrm{K}^{+}$-ATPase, isolated by gel electrophoresis, as described (14). The amino acid composition determined for the protein blotted onto the polyvinylidene fluoride (PVDF) membranes showed good agreement with the expected composition for $\mathrm{Na}^{+}, \mathrm{K}^{+}$-ATPase.

Free calcium concentrations were calculated as described (15), taking into account the multiple equilibria of $\mathrm{Ca}^{2+}, \mathrm{Mg}^{2+}, \mathrm{ATP}$, and EGTA, and the $\mathrm{pH}$.

Phosphorylation of histone by PKC. Phosphorylation was performed under linear assay conditions using $10 \mu \mathrm{M}$ histone (type III from calf thymus) as substrate and the assay conditions described above. $10 \mu \mathrm{g} / \mathrm{ml} \mathrm{L}-\alpha$-phosphatidylserine and $1 \mu \mathrm{M}$ 1-oleoyl-2-acetoyl$s n$-glycerol (OAG) were added to the reaction mediums indicated. Reactions were stopped by the addition of $30 \%$ acetic acid and aliquots were spotted on phosphocellulose filters (P81; Whatman Inc., Clifton, NJ). Filters were washed in water for $10 \mathrm{~min}$ and then counted in a liquid scintillation counter.

Two-dimensional phosphopeptide mapping. For phosphopeptide mapping of $\mathrm{Na}^{+}, \mathrm{K}^{+}$-ATPase, gel pieces containing labeled $\mathrm{Na}^{+}, \mathrm{K}^{+}$ATPase $\alpha_{1}$ subunit were excised from dried gels, washed, incubated with trypsin, and processed as described (16). Briefly, aliquots were spotted in the middle of the plate, $4 \mathrm{~cm}$ from the bottom, and initially separated by horizontal electrophoresis at $\mathrm{pH} 3.5$ in $10 \%$ acetic acid/ $1 \%$ pyridine until the dye front migrated $7 \mathrm{~cm}$. Chromatography was performed in the vertical dimension in 1-butanol/acetic acid/water/ pyridine (15:3:12:10 vol/vol, respectively). Phosphopeptides were visualized by autoradiography.

Cell culture. COS cells were maintained at $37^{\circ} \mathrm{C}$ in a humified atmosphere of $95 \% \mathrm{O}_{2}$ and $5 \% \mathrm{CO}_{2}$, in DMEM supplemented with $10 \%$ fetal serum. Cells were grown to confluence for $4-5 \mathrm{~d}$ in $10-\mathrm{cm}$ dishes.

Analysis of PKC distribution in COS cells. (a) Subcellular fractionation. After a 30-min incubation with DMEM alone (control group) or with the addition of experimental drugs, cell monolayers were washed with ice-cold PBS, scraped in $1 \mathrm{ml}$ homogenization buffer (HB) (20 mM Tris-HCl, $2 \mathrm{mM}$ EGTA, $2 \mathrm{mM}$ EDTA, $1 \mathrm{mM}$ phenylmethylsulfonylfluoride, $10 \mathrm{mM} \beta$-mercaptoethanol, and 100 $\mathrm{KIE} / \mathrm{ml}$ aprotinin), homogenized and pelleted by centrifugation at $100,000 \mathrm{~g}$ for $1 \mathrm{~h}$ at $4^{\circ} \mathrm{C}$. Membrane fractions were solubilized in HB plus $0.1 \%$ triton $\times 100$. Protein concentrations were determined according to Bradford (17). (b) PKC immunoblotting. Cytosolic and membrane samples containing equal amounts of protein $(10 \mu \mathrm{g})$ were dissolved in loading buffer ( $1 \%$ SDS, $0.25 \mathrm{mM}$ Tris- $\mathrm{HCl}, 10 \%$ glycerol, $5 \% \beta$-mercaptoethanol, and trace amounts of pyronine), and separated by SDS-PAGE ( $8 \%$ acrylamide), transferred to nitrocellulose and immunoblotted with a PKC $\alpha$ isozyme-specific antipeptide antibody (Santa Cruz Biotechnology, Santa Cruz, CA) as described (9). After washing, filters were incubated with peroxidase-conjugated anti-rabbit polyclonal antibodies (Amersham International, Little Chalfont, UK) and detected using an enhanced chemiluminescence method (Amersham International).

Site-directed mutagenesis and DNA transfection into COS cells. Ser23 of rat $\alpha_{1} \mathrm{Na}^{+}, \mathrm{K}^{+}$-ATPase was mutated to alanine using the methods described in detail elsewhere (18). In brief, site-directed mutagenesis was carried out by PCR using as template rat $\mathrm{Na}^{+}, \mathrm{K}^{+}$ATPase $\alpha_{1}$ cDNA cloned in the pCMV eukaryotic expression vector (PharMingen, San Diego, CA). The presence of the correct mutation was confirmed by direct nucleotide sequencing according to Sanger et al. (19). The entire cDNAs coding for wild-type and mutated $\alpha_{1}$ were transfected into a Green Monkey kidney cell line (COS cells) using the $\mathrm{CaPO}_{4} / \mathrm{DNA}$ coprecipitation method. Since the endogenous $\operatorname{COS} \mathrm{Na}^{+}, \mathrm{K}^{+}$-ATPase has a higher sensitivity to ouabain than the rat $\alpha_{1}$ subunit $\mathrm{Na}^{+}, \mathrm{K}^{+}$-ATPase, the cells were grown in a medium containing $10^{-5} \mathrm{M}$ ouabain. Untransfected COS cells did not survive in this medium. To avoid problems arising from clonal variation, a total of $\sim 100$ colonies were selected, pooled, and used in all the studies.

Ouabain-sensitive ${ }^{86} \mathrm{Rb}^{+}$uptake and $\mathrm{Na}^{+}, \mathrm{K}^{+}$-ATPase activity in transfected COS cells. Cell monolayers were washed twice with room temperature $\mathrm{PBS}$ and preincubated for $30 \mathrm{~min}$ at room temperature with 20 HETE $(1 \mu \mathrm{M})$. All measurements were made in the presence of $10^{-5} \mathrm{M}$ ouabain to inhibit endogenous $\mathrm{Na}^{+}, \mathrm{K}^{+}$-ATPase activity. Protein content was determined by the method of Bradford (17).

${ }^{86} \mathrm{Rb}^{+}$uptake, used as an index of $\mathrm{K}^{+}$uptake (20), was initiated by addition of $0.1 \mathrm{ml} /$ well PBS containing $25 \mu \mathrm{Ci} / \mathrm{ml}^{86} \mathrm{Rb}^{+}$and was linear for at least $5 \mathrm{~min}$. Recordings were made at 2-min intervals. Reactions were stopped by aspiration of the medium and rinsing the cells three times with $1 \mathrm{ml} /$ well of ice-cold PBS, containing $5 \mathrm{mM} \mathrm{BaCl}_{2}$. Cells were then lysed twice with $0.55 \mathrm{ml}$ of $1 \mathrm{mM} \mathrm{NaOH}$. Radioactivity in cell lysates was measured by liquid scintillation counting (LKB, Wallac, Sweden). $\mathrm{Na}^{+}, \mathrm{K}^{+}$-ATPase activity was determined as the difference between ${ }^{86} \mathrm{Rb}^{+}$uptake in the absence (total activity) and presence (ouabain-insensitive) of ouabain and was expressed as micromoles per minute per milligram protein.

The activity of $\mathrm{Na}^{+}, \mathrm{K}^{+}$-ATPase was assayed in a crude membrane preparation as described above. To prevent dephosphorylation of $\mathrm{Na}^{+}, \mathrm{K}^{+}$-ATPase, the buffer was complemented with the protein phosphatase inhibitors okadaic acid $(250 \mathrm{nM})$ and FK506 (25 nM). An amount of enzyme was selected so that total ATP hydrolysis did not exceed $20 \%$, and ATP hydrolysis was linear with time. The reaction was stopped by the addition of $700 \mu l$ of activated charcoal. The ${ }^{32} \mathrm{P}$ liberated was determined in the supernatant after centrifugation. For the determination of ouabain-insensitive rat ATPase activity, $\mathrm{NaCl}$ and $\mathrm{KCl}$ were omitted and $5 \mathrm{mM}$ ouabain was added. $\mathrm{Na}^{+}, \mathrm{K}^{+}$ATPase activity is expressed as picomoles inorganic phosphate (Pi) per hour per milligram protein.

Chemicals. GF109203x was purchased from Calbiochem Corp. (La Jolla, CA), RO318220 was a kind gift from Roche Products LTD (London, UK). Both of these PKC antagonists were stored as stock solutions in DMSO at $-20^{\circ} \mathrm{C}$. Further dilutions were made in dissection solution. Control experiments showed that, at the concentrations used, DMSO did not interfere with $\mathrm{Na}^{+}, \mathrm{K}^{+}$-ATPase activity. Both GF109203 and RO318220, which are bisindolyl maleimides, are highly specific inhibitors for PKC with $\mathrm{IC}_{50} 30-200 \mathrm{nM}$ and $23 \mathrm{nM}$, respectively $(21,22)$. Other kinases are affected at much higher concentrations. The $\mathrm{IC}_{50}$ for PKA is $>10 \mu \mathrm{M}$. All these $\mathrm{IC}_{50}$ values were recorded for purified enzyme. GF109203 was used in the concentration of $1 \mu \mathrm{M}$ and RO318220 in the concentrations of $0.1 \mu \mathrm{M}$.

PKC was obtained from Boehringer Mannheim (Mannheim, Germany), 1-oleoyl-2-acetoyl-sn-glycerol from Avanti Polar Lipids, Inc. (Alabaster, AL), 20-hydroxyeicosa-tetraenoic acid from Cascade Biochem LTD (Berkshire, UK).

Statistics. Statistical comparisons between two groups were performed by Student's $t$ test for unpaired data. Comparisons between several groups were done by analysis of variance. $P<0.05$ were considered significant. 


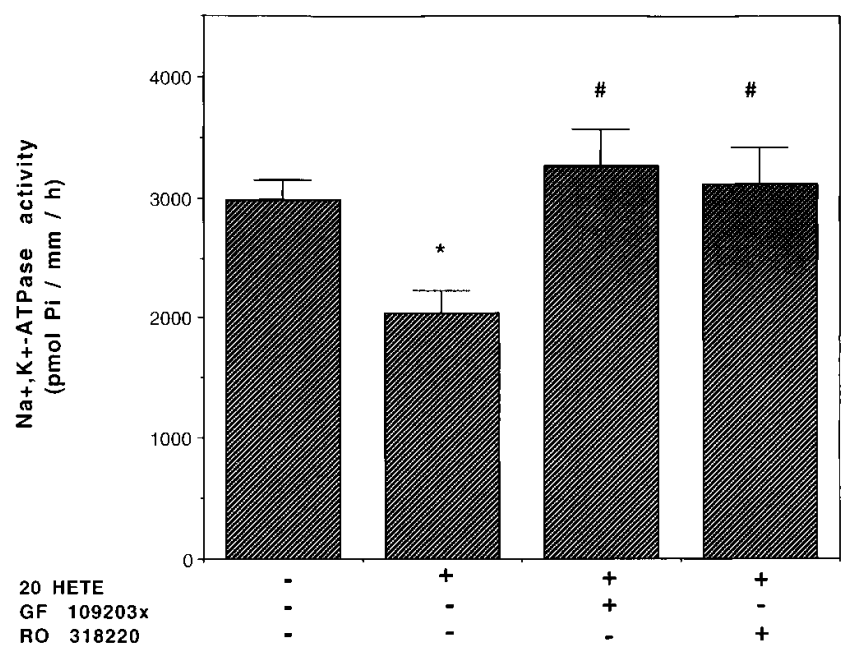

Figure 1. $\mathrm{Na}^{+}, \mathrm{K}^{+}$-ATPase activity in isolated proximal tubules. Individual tubular segments were incubated at room temperature for 30 min in a drug free medium (control, $n=17$ ), or in the presence of the indicated drugs: 20 HETE $\left(10^{-6} \mathrm{M}\right)(n=13), 20 \mathrm{HETE}\left(10^{-6} \mathrm{M}\right)$ plus GF109203x $\left(10^{-6} \mathrm{M}\right)(n=5), 20 \mathrm{HETE}\left(10^{-6} \mathrm{M}\right)$ plus RO318220 $\left(10^{-7} \mathrm{M}\right)(n=5)$. The PKC inhibitors were present $5 \mathrm{~min}$ before and throughout the incubation with 20 HETE. Each bar represents the mean \pm SEM. Statistical comparison between groups was done by one-way analysis of variance followed by Tukey-Kramer test. $* P<$ 0.05 vs. control, ${ }^{\#} P<0.05$ vs. 20 HETE.

\section{Results}

Inhibition of renal tubular $\mathrm{Na}^{+}, \mathrm{K}^{+}$-ATPase by $20 \mathrm{HETE}$ is abolished by PKC inhibitors. $\mathrm{Na}^{+}, \mathrm{K}^{+}$-ATPase activity in proxi-

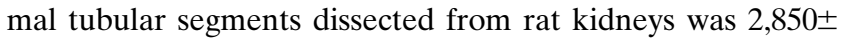
$112 \mathrm{pmol} \mathrm{Pi} \mathrm{mm}{ }^{-1} \mathrm{~h}^{-1}(n=17)$. $20 \operatorname{HETE}\left(10^{-10}\right.$ to $\left.10^{-5} \mathrm{M}\right)$ inhibited $\mathrm{Na}^{+}, \mathrm{K}^{+}$-ATPase activity in a dose-dependent manner in accordance with data already published (5). Inhibition was first observed at $10^{-9} \mathrm{M} 20 \mathrm{HETE}$ and was maximal (25\% inhibition) at $10^{-7} \mathrm{M}(P<0.05, n=3)$ (data not shown). $20 \mathrm{HETE}$ at concentrations from $10^{-9}-10^{-4} \mathrm{M}$ had no effect on purified rat renal $\mathrm{Na}^{+}, \mathrm{K}^{+}$-ATPase (data not shown), suggesting that the effect of 20 HETE on tubular $\mathrm{Na}^{+}, \mathrm{K}^{+}$-ATPase activity is not due to a direct interaction between the lipid and the pump.

To assess whether the inhibitory effect of 20 HETE was mediated via PKC, proximal tubular segments were first incubated with 20 HETE $\left(10^{-6} \mathrm{M}\right)$ in the presence of two different PKC inhibitors: GF109203x $\left(10^{-6} \mathrm{M}\right)$ or RO318220 $\left(10^{-7} \mathrm{M}\right)$. In this protocol, incubation of tubules with 20 HETE alone resulted in $27 \pm 4 \%$ inhibition of $\mathrm{Na}^{+}, \mathrm{K}^{+}$-ATPase activity $(P<$ 0.05 vs. control, $n=9)$. The effect of 20 HETE was abolished by GF109203x and RO318220 $(P<0.05$ vs. 20 HETE in paired experiments for both drugs) (Fig. 1). The addition of the PKC inhibitors alone had no effect on $\mathrm{Na}^{+}, \mathrm{K}^{+}$-ATPase activity (data not shown).

20 HETE does not inhibit the activity of $\mathrm{Na}^{+}, \mathrm{K}^{+}$-ATPase after mutation of the PKC regulatory site. The site for PKC phosphorylation in rat $\alpha_{1}$ subunit of $\mathrm{Na}^{+}, \mathrm{K}^{+}$-ATPase was recently identified as Ser23 $(13,23)$. cDNAs coding for wild-type rat $\mathrm{Na}^{+}, \mathrm{K}^{+}$-ATPase $\alpha_{1}$ subunit or rat $\alpha$ subunit in which Ser 23 had been mutated to alanine (S23A) were stably transfected into COS cells. Total ${ }^{86} \mathrm{Rb}^{+}$uptake was similar in cells expressing
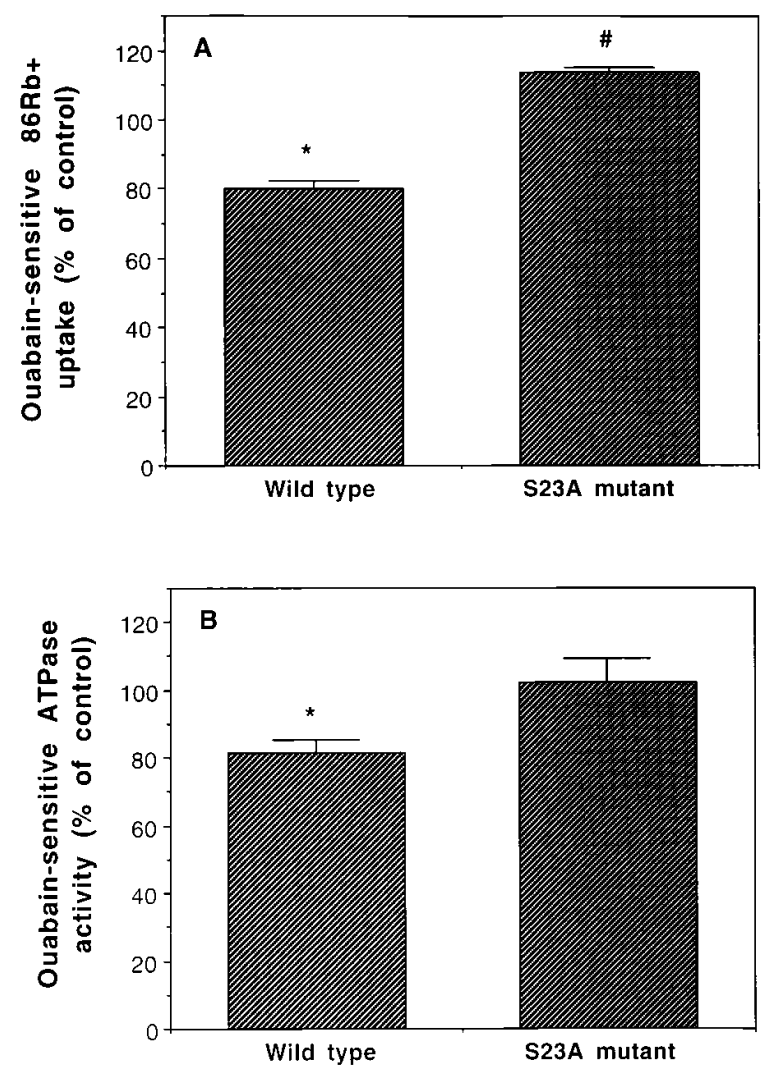

Figure 2. Effect of $20 \mathrm{HETE}$ on ouabain-sensitive ${ }^{86} \mathrm{Rb}^{+}$uptake and $\mathrm{Na}^{+}, \mathrm{K}^{+}$-ATPase activity in transfected COS cells. Cells were transfected with rat wild-type $\alpha_{1}$ subunit or with the S23A mutant and preincubated in the presence or absence of $1 \mu \mathrm{M} 20$ HETE for $30 \mathrm{~min}$ at room temperature. Ouabain-sensitive ${ }^{86} \mathrm{Rb}^{+}$uptake $(A)$ and $\mathrm{Na}^{+}, \mathrm{K}^{+}$ATPase activity $(B)$ were assayed as described in Methods. In control groups (incubation without drugs), ouabain-sensitive ${ }^{86} \mathrm{Rb}^{+}$uptake and $\mathrm{Na}^{+}, \mathrm{K}^{+}$-ATPase activity were $22.9 \pm 0.5 \mathrm{pmol} / \mathrm{min}$ per $\mathrm{mg}$ protein and $4,497 \pm 305 \mathrm{pmol} \mathrm{Pi} / \mathrm{h}$ per $\mathrm{mg}$ protein, respectively, for cells expressing wild-type $\mathrm{Na}^{+}, \mathrm{K}^{+}$-ATPase. For cells expressing S23A $\mathrm{Na}^{+}, \mathrm{K}^{+}$-ATPase, the corresponding values were $21.7 \pm 1.3 \mathrm{pmol} / \mathrm{min}$ per $\mathrm{mg}$ protein and $2,780 \pm 672 \mathrm{pmol} \mathrm{Pi} / \mathrm{h}$ per $\mathrm{mg}$ protein, respectively. Each bar represents the mean \pm SEM of four experiments. $* P<0.01$ vs. control by Student's $t$ test for unpaired data.

wild-type and S23A $\mathrm{Na}^{+}, \mathrm{K}^{+}$-ATPase. $20 \mathrm{HETE}$ decreased ouabain-sensitive ${ }^{86} \mathrm{Rb}^{+}$uptake by $19.7 \pm 1.0 \%$ in COS cells expressing wild-type $\mathrm{Na}^{+}, \mathrm{K}^{+}$-ATPase $(P<0.001$ vs. control, $n=5)$. In contrast, 20 HETE caused a small, but significant increase of $14.3 \pm 2.0 \%$ in ${ }^{86} \mathrm{Rb}^{+}$uptake in cells expressing the S23A mutant $(P<0.02$ vs. control, $n=4)$ (Fig. $2 A)$. Ouabaininsensitive ${ }^{86} \mathrm{Rb}^{+}$uptake was unaffected by 20 HETE in both cell types (data not shown). In ongoing studies, we have observed that in the presence of phorbol 12,13-dibutyrate (PDBu), ouabain-sensitive ${ }^{86} \mathrm{Rb}^{+}$uptake is decreased in cells expressing rat wild-type $\mathrm{Na}^{+}, \mathrm{K}^{+}$-ATPase, but increased in cells expressing rat $\mathrm{S} 23 \mathrm{~A} \mathrm{Na}^{+}, \mathrm{K}^{+}$-ATPase. This increase could, in the case of PDBu be attributed to a PKC-mediated stimulation of $\mathrm{Na}^{+}$ uptake via the $\mathrm{Na}^{+}-\mathrm{H}^{+}$exchanger (Belusa, R., Z.-M. Wang, T. Matsubara, B. Sahlgren, I. Dulubova, A.C. Nairn, E. Ruoslahti, P. Greengard, and A. Aperia, manuscript in preparation).

Treatment with 20 HETE induced an $18.3 \pm 1.7 \%$ inhibition of $\mathrm{Na}^{+}, \mathrm{K}^{+}$-ATPase activity in COS cells expressing wild-type 


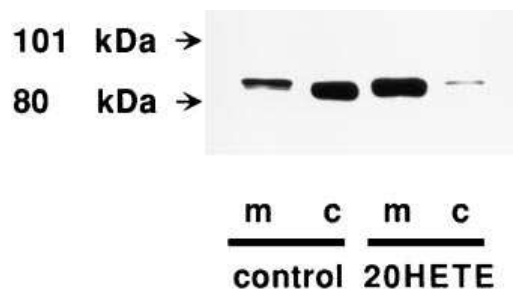

or 20 HETE $(1 \mu \mathrm{M})$ for

$30 \mathrm{~min}$ at room temperature were prepared as described in Methods, subjected to SDS-PAGE (10 ng protein/lane), transferred to nitrocellulose, and immunoblotted with an antipeptide antibody specific for $\mathrm{PKC} \alpha$.

$\mathrm{Na}^{+}, \mathrm{K}^{+}$-ATPase $(P<0.01$ vs. control, $n=4)$, but had no effect in cells expressing S23A Na+, $\mathrm{K}^{+}$-ATPase (Fig. 2 B). Ouabain-insensitive ATPase activity was unaffected by 20 HETE in both cell types (data not shown).

20 HETE induces translocation of PKC from the cytoplasm to the membrane. The initial step in the activation of many $\mathrm{PKC}$ isoforms, including the ubiquitous $\mathrm{PKC} \alpha$, is the translocation of the enzyme from the cytosol to the membrane (24). Incubation of intact COS cells with $20 \operatorname{HETE}(1 \mu \mathrm{M})$ for 30 min caused a pronounced decrease in cytosolic PKC $\alpha$, along with a concomitant, approximately twofold, increase in PKC $\alpha$ associated with the membrane fraction (Fig. 3). Similar results were observed when PDBu, a classical PKC activator, was used (data not shown).

20 HETE enhances phosphorylation of $\mathrm{Na}^{+}, \mathrm{K}^{+}-A T P a s e$ by $P K C$. The calcium dependence of the phosphorylation by PKC of the purified rat kidney $\mathrm{Na}^{+}, \mathrm{K}^{+}$-ATPase $\alpha_{1}$, was evaluated. As expected, a relationship between calcium and $\mathrm{Na}^{+}, \mathrm{K}^{+}$ATPase $\alpha_{1}$ subunit phosphorylation was found with a thresh-

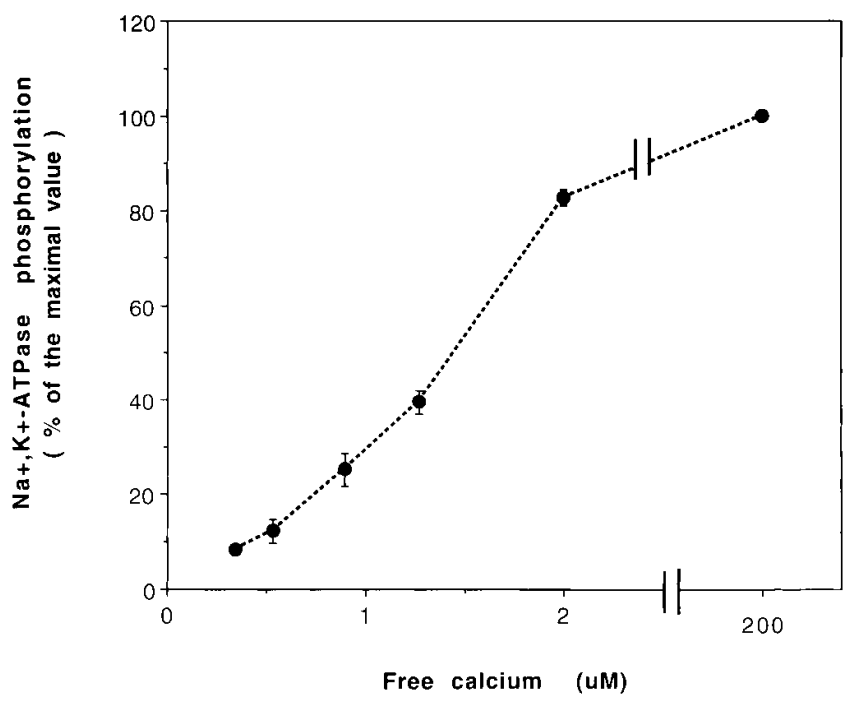

Figure 4. $\mathrm{Ca}^{2+}$ dependence of $\mathrm{Na}^{+}, \mathrm{K}^{+}$-ATPase phosphorylation by PKC. $1 \mu \mathrm{g}$ purified $\mathrm{Na}^{+}, \mathrm{K}^{+}$-ATPase was incubated with $\mathrm{PKC}$ at $24^{\circ} \mathrm{C}$ in a phosphorylation mixture as described in Methods for $20 \mathrm{~min}$ at various calcium concentrations. The stoichiometry of phosphorylation measured at $200 \mu \mathrm{M}$ calcium at steady state conditions was 0.6 mol Pi incorporated per mol of $\mathrm{Na}^{+}, \mathrm{K}^{+}$-ATPase. Data were normalized to the maximal phosphorylation signal from the same experiment (obtained at $200 \mu \mathrm{M}$ free calcium). Each point represents the mean \pm SEM from two to four experiments.
A
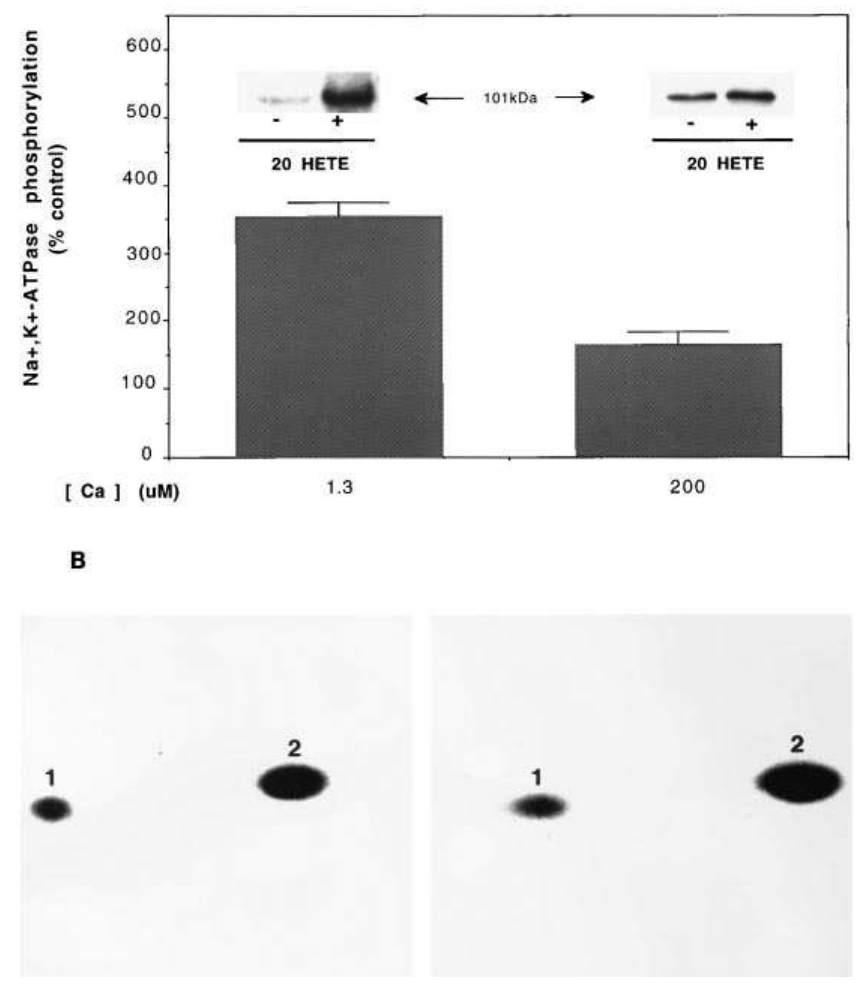

Figure 5. (A) Effect of 20 HETE on PKC-dependent $\mathrm{Na}^{+}, \mathrm{K}^{+}$-ATPase phosphorylation. $1 \mu \mathrm{g}$ of purified $\mathrm{Na}^{+}, \mathrm{K}^{+}$-ATPase was incubated with PKC at $24^{\circ} \mathrm{C}$ for $2 \mathrm{~min}$ in the presence of the indicated $\mathrm{Ca}^{2+}$ concentration, in the absence (control) or presence of $100 \mu \mathrm{M} 20$ HETE. Data are expressed as the increase in the phosphorylation signal in the presence of 20 HETE over the control value for each experiment. Bars represent means \pm SEM from three experiments. An autoradiogram from a representative experiment is included in the inset. $(B)$ Two-dimensional phosphopeptide mapping of $\mathrm{Na}^{+}, \mathrm{K}^{+}$-ATPase phosphorylated by $\mathrm{PKC}$ in the absence (left) or presence (right) of $100 \mu \mathrm{M}$ 20 HETE. Phosphorylation was run for 3 min under the conditions described above. Electrophoresis was performed in the horizontal direction (positive electrode left) and chromatography was performed in the vertical direction.

old calcium concentration of $\sim 0.5 \mu \mathrm{M}$ (Fig. 4). Time course studies were performed at both saturating $(200 \mu \mathrm{M})$ and nonsaturating $(1.3 \mu \mathrm{M})$ calcium concentrations. In both conditions, $\mathrm{Na}^{+}, \mathrm{K}^{+}$-ATPase phosphorylation by PKC was linear during the first 2 min of incubation. 20 HETE $(1-170 \mu \mathrm{M})$ increased $\mathrm{Na}^{+}, \mathrm{K}^{+}$-ATPase phosphorylation by PKC in a dosedependent manner, with a threshold concentration of $20 \mu \mathrm{M}$ (data not shown).

The effect of 20 HETE $(100 \mu \mathrm{M})$ on the PKC-dependent phosphorylation of $\mathrm{Na}^{+}, \mathrm{K}^{+}$-ATPase was studied at two different calcium concentrations $(1.3$ and $200 \mu \mathrm{M})$ under conditions of linearity (Fig. $5 \mathrm{~A}$ ). Phosphorylation of $\mathrm{Na}^{+}, \mathrm{K}^{+}$-ATPase by PKC was enhanced by 20 HETE, mainly at the lower calcium concentration.

Two-dimensional phosphopeptide maps of the phosphorylated $\alpha$ subunit indicated that the same site in the purified enzyme was phosphorylated by PKC, both in control conditions and in the presence of 20 HETE (Fig. 5 B). 

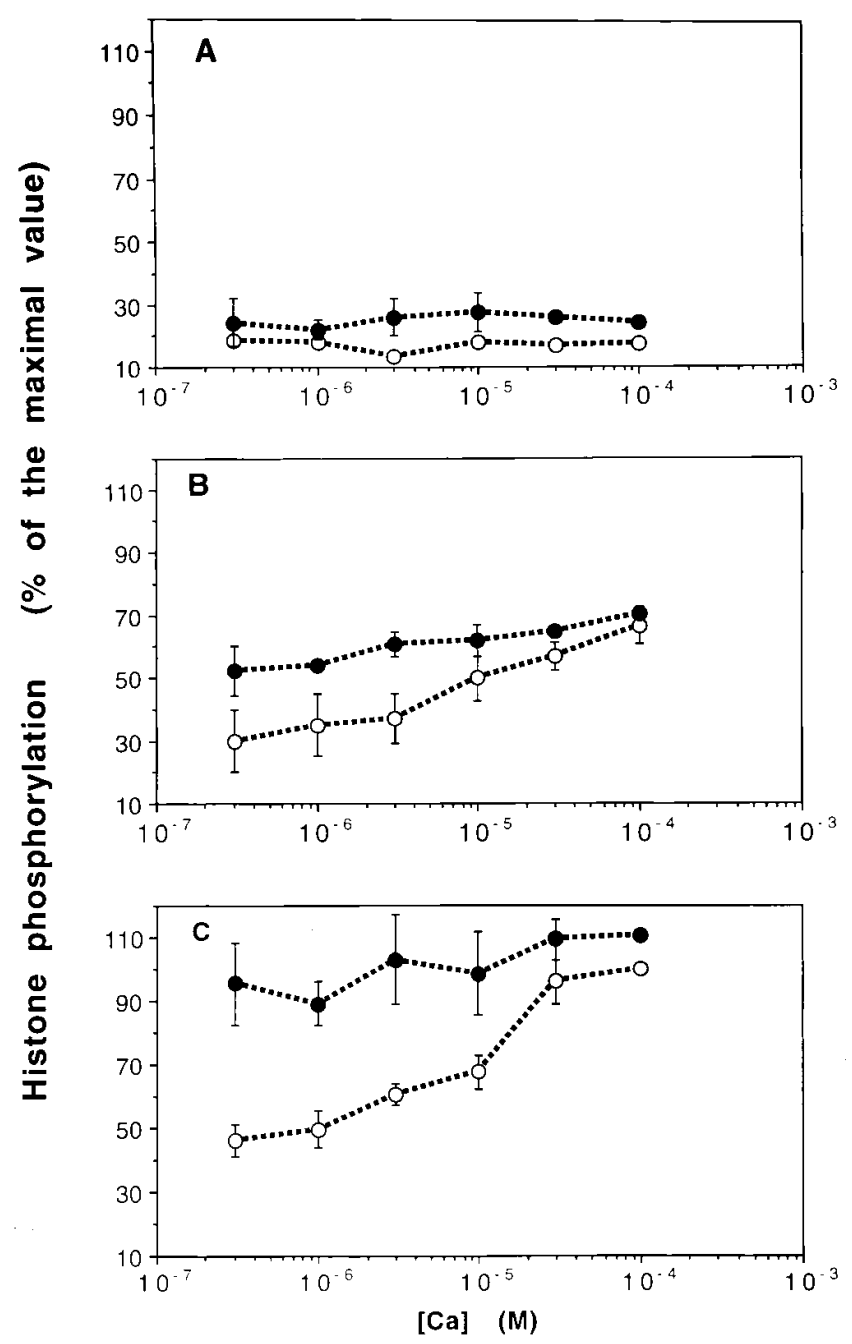

Figure 6. Calcium dependence of PKC activity in the absence and presence of 20 HETE. PKC activity was assayed using histone as the substrate under linear and standard conditions (see Methods) except that various concentrations of $\mathrm{CaCl}_{2}$ were added in the absence $(O)$ or presence $(\bullet)$ of 20 HETE $(50 \mu \mathrm{M})$. Other lipids were added to the incubation medium as follows: $A$, none; $B$, phosphatidylserine $(10 \mu \mathrm{g} /$ $\mathrm{ml}) ; C$, phosphatidylserine $(10 \mu \mathrm{g} / \mathrm{ml})$ plus OAG $(1 \mu \mathrm{M})$. Data were normalized to the phosphorylation signal obtained at $10^{-4} \mathrm{M}$ calcium in the presence of phosphatidylserine plus OAG. For each group, histone phosphorylation was also studied under completely calcium free conditions. In these protocols, EGTA $(5 \mathrm{mM})$ was added to the reaction mixture instead of $\mathrm{CaCl}_{2}$. Under these conditions, histone phosphorylation (percentage of the maximal value) were as follows: control, 17.4 $\pm 1.5,23.0 \pm 10$, and $44.1 \pm 7$ for $A, B$, and $C$, respectively, and in the presence of $20 \mathrm{HETE}(50 \mu \mathrm{M}), 19.4 \pm 2.6,40.7 \pm 3.6$, and $59.7 \pm 14$ for $A, B$, and $C$, respectively. Each point represents the mean \pm SEM from two to three experiments.

It is well known that unsaturated fatty acids are extremely difficult to maintain in solution. The major difficulties are related to the adsorption of the fatty acids to tubing and to their poor solubility (25). In most previous in vitro studies on the effect of unsaturated fatty acids on PKC, doses up to $100 \mu \mathrm{M}$ have been used $(26,27)$. The intact cells responded to a lower dose of $20 \mathrm{HETE}$, namely $1 \mu \mathrm{M}$. It is possible that conditions for the in vitro studies are less favorable for the maintenance of 20 HETE than the conditions for the intact cell studies. It is also possible that in the intact cell the effect of $20 \mathrm{HETE}$ is amplified for instance by the presence of synergizing fatty acids (28).

20 HETE enhances phosphorylation of histone by PKC. To evaluate if the effect of 20 HETE on phosphorylation of $\mathrm{Na}^{+}, \mathrm{K}^{+}$-ATPase by PKC was due to a direct effect on PKC or on $\mathrm{Na}^{+}, \mathrm{K}^{+}$-ATPase, we also studied the effect of 20 HETE on the phosphorylation of histone by PKC. Histone phosphorylation was slightly enhanced by the presence of $50 \mu \mathrm{M} 20$ HETE. This effect was calcium independent (Fig. $6 \mathrm{~A}$ ). The interaction between $20 \mathrm{HETE}$, phosphatidylserine, and the diacylglycerol analogue, OAG was also studied. In the presence of phosphatidylserine $(10 \mu \mathrm{g} / \mathrm{ml})$, phosphorylation of histone by PKC was calcium dependent. The concentration dependence for calcium-stimulated phosphorylation of histone by $\mathrm{PKC}$ in the presence of phosphatidylserine was markedly shifted to the left by 20 HETE. The maximal response was unaffected by 20 HETE (Fig. 6 B). As expected, the OAG and phosphatidylserine-dependent activation of PKC was also calcium dependent and was greatly enhanced by the addition of 20 HETE (Fig. 6 C).

\section{Discussion}

Previous studies have demonstrated that arachidonic acid activates PKC (26-30), that this effect is associated with an increase in the affinity for calcium, and that certain unsaturated fatty acids act synergistically with diacylglycerol and phosphatidylserine to activate $\operatorname{PKC}(26,27)$. In another series of studies, it was shown that certain P-450 metabolites of arachidonic acid regulate the activity of $\mathrm{Na}^{+}, \mathrm{K}^{+}$-ATPase (5-7). The results of the present study indicate that 20 HETE-dependent inhibition of rat renal $\mathrm{Na}^{+}, \mathrm{K}^{+}$-ATPase activity is mediated via PKC. Thus PKC inhibitors abolished the inhibitory effect of $20 \mathrm{HETE}$ on $\mathrm{Na}^{+}, \mathrm{K}^{+}$-ATPase activity and this effect was also abolished in $\mathrm{Na}^{+}, \mathrm{K}^{+}$-ATPase in which the PKC phosphorylation site (S23) was mutated to alanine. Two other lines of evidence indicate that the effect of $20 \mathrm{HETE}$ was due to an effect on PKC and not on the $\mathrm{Na}^{+}, \mathrm{K}^{+}$-ATPase itself; first, $20 \mathrm{HETE}$ had no effect on the activity of purified $\mathrm{Na}^{+}, \mathrm{K}^{+}$-ATPase in the absence of PKC; second, 20 HETE stimulated PKC-dependent phosphorylation of histone.

Rat renal $\alpha_{1} \mathrm{Na}^{+}, \mathrm{K}^{+}$-ATPase is a physiological substrate for $\operatorname{PKC}(8,13,14)$. Many studies, performed either on intact rat renal tubular cells or on purified enzyme, suggest that PKC phosphorylation of rat $\mathrm{Na}^{+}, \mathrm{K}^{+}$-ATPase is associated with a decrease in enzyme activity $(8-10,13,31)$, although in one study a stimulatory effect of phorbol ester on enzyme activity was found (32).

The present study suggests that 20 HETE may act as a second messenger, mediating the actions of hormones on phosphorylation of rat $\alpha_{1} \mathrm{Na}^{+}, \mathrm{K}^{+}$-ATPase by PKC. 20 HETE was shown to activate $\mathrm{PKC}$ both in the in vitro phosphorylation studies and in intact cells. In the in vitro studies, 20 HETE was found to reduce the concentration of calcium required for the phosphatidylserine-dependent activation of $\mathrm{PKC}$, regardless of whether histone or $\mathrm{Na}^{+}, \mathrm{K}^{+}$-ATPase was used as a substrate. The results are in agreement with the findings that several cisunsaturated fatty acids, including arachidonic acid, can enhance the affinity of PKC for calcium (27). In intact cells, 20 HETE facilitated the translocation of the calcium-dependent 
PKC $\alpha$ from the cytosol to the membrane, a process that is also calcium dependent. 20 HETE mimicked the action of diacylglycerol and phorbol ester both with regard to the effects on histone phosphorylation and with regard to PKC translocation.

Our present results suggest a synergism between 20 HETE, phosphatidylserine, and the diacylglycerol analogue that was more pronounced at physiological intracellular calcium levels. Activation of phospholipase $\mathrm{C}$ leads to the release of inositol triphosphate and a transient increase in intracellular free calcium (33). In contrast, activation of $\mathrm{PLA}_{2}$ is generally not associated with an increase in intracellular calcium. The present results suggest that the calcium-dependent PKC isoforms expressed in the kidney, $\alpha$ and $\gamma(34)$, can be activated by the $\mathrm{PLA}_{2}$ pathway at resting intracellular calcium concentrations.

The expression of the arachidonic acid metabolizing P-450 enzymes is highly tissue specific (35). It is important to realize that the $\mathrm{PLA}_{2}-\mathrm{PKC}$ signaling pathway may be mediated by arachidonic acid metabolites other than 20 HETE. Thus, a number of biological effects of lipoxygenase metabolites are mediated through the stimulation of PKC. 15(S)-hydroperoxy5,8,11,13-eicosa-tetraenoic acid (15(S)-HPETE) was, at micromolar concentration, found to induce transmigration of monocytes across an endothelial monolayer. This effect was attenuated in the presence of PKC inhibitors (36). 12(S)Hydroxyeicosatetraenoic acid (12(S)-HETE) (0.1 $\mu \mathrm{M})$ was found to induce the release of cathepsin B. This effect was abolished in the presence of PKC inhibitors (37).

In ongoing studies, we have found that the lipoxygenase metabolite 12(S)-HETE enhances PKC-induced phosphorylation of $\mathrm{Na}^{+}, \mathrm{K}^{+}$-ATPase in vitro and inhibits proximal tubule $\mathrm{Na}^{+}, \mathrm{K}^{+}$-ATPase activity (data not shown).

The results from the present study have important implications for an understanding of the $\mathrm{PLA}_{2}$-arachidonic acid signaling pathway in the kidney as well as in other tissues. Both dopamine and parathyroid hormone have been shown to inhibit renal tubular $\mathrm{Na}^{+}, \mathrm{K}^{+}$-ATPase via the $\mathrm{PLA}_{2}$-arachidonic acid-20 HETE pathway (5-7). Several other hormones, such as vasopressin and EGF, are known to activate $\mathrm{PLA}_{2}$ in the kidney (38). It is possible that the effects of these hormones, which can influence tubular transport, renal hemodynamics, and kidney growth and differentiation are also mediated via PKC. In addition to inhibiting tubular $\mathrm{Na}^{+}, \mathrm{K}^{+}$-ATPase activity, 20 HETE has several other biological effects, such as induction of vasoconstriction (39) and inhibition of $\mathrm{K}^{+}$channels (40). The possibility that these effects are also mediated via PKC should be considered.

\section{Acknowledgments}

The authors thank Mona Agrén and Eivor Zettergren for their excellent technical assistance.

This work has been supported by grants from the Swedish Medical Research Council (03644), the Swedish Heart Lung Foundation, and Tielman's Foundation.

\section{References}

1. Khan, W.A., G.C. Blobe, and Y.A. Hannun. 1995. Arachidonic acid and free fatty acids as second messengers and the role of protein kinase C. Cell. Signalling. 7:171-184.

2. Schwartzman, M.L., and N.G. Abraham. 1992. The renal cytochrome P-450 arachidonic acid system. Pediatr. Nephrol. 6:490-498.
3. Schwartzman, M.L., N.R. Ferreri, M.A. Carroll, E. Songu-Mize, and J.C. McGiff. 1985. Renal cytochrome P450-related metabolite inhibits $\left(\mathrm{Na}^{+}+\mathrm{K}^{+}\right)$ ATPase. Nature (Lond.). 314:620-622.

4. Escalante, B., D. Erlij, J.R. Falck, and J.C. McGriff. 1993. Cytochrome P450-dependent arachidonate metabolites affect renal transport in the rabbit. $J$. Cardiovasc. Pharmacol. 22:S106-S108.

5. Pedrosa Ribeiro, C.M., G.R. Dubay, J.R. Falck, and L.J. Mandel. 1994. Parathyroid hormone inhibits $\mathrm{Na}^{+}-\mathrm{K}^{+}$-ATPase through a cytochrome P-450 pathway. Am. J. Physiol. 266:F497-F505.

6. Satoh, T., H.T. Cohen, and A. I. Katz. 1993. Intracellular signalling in the regulation of renal Na-K-ATPase. Role of eicosanoids. J. Clin. Invest. 91:409415 .

7. Ominato, M., T. Satoh, and A.I. Katz. 1996. Regulation of Na-K-ATPase activity in the proximal tubule: role of the protein kinase $\mathrm{C}$ pathway and of eicosanoids. J. Membr. Biol. 152:235-243.

8. Bertorello, A., and A. Aperia. 1989. $\mathrm{Na}^{+}, \mathrm{K}^{+}$-ATPase is an effector protein for protein kinase $\mathrm{C}$ in renal proximal tubule cells. Am. J. Physiol. 256: F370-F373.

9. Middleton, J.P., W.A. Khan, G. Collinsworth, Y.A. Hannun, and R.M. Medford. 1993. Heterogeneity of protein kinase C-mediated rapid regulation of Na/K-ATPase in kidney epithelial cells. J. Biol. Chem. 268:15958-15964.

10. Vasilets, L.A., and W. Schwarz. 1992. Regulation of endogenous and expressed $\mathrm{Na}^{+} / \mathrm{K}^{+}$pump in Xenopus Oocytes by membrane potential and stimulation of protein kinases. J. Membr. Biol. 125:119-132.

11. Jorgensen, P.L. 1974. Isolation of $\left(\mathrm{Na}^{+}\right.$plus $\left.\mathrm{K}^{+}\right)$-ATPase. Methods Enzymol. 32:277-290.

12. Celsi, G., A. Nishi, G. Akusjarvi, and A. Aperia. 1991. Abundance of NaKATPase mRNA is regulated by glucocorticoid hormones in the infant rat kidney. Am. J. Physiol. 260:F192-F197.

13. Logvinenko, N.S., I. Dulubova, N. Fedosova, S.H. Larsson, A.C. Nairn, M. Esmann, P. Greengard, and A. Aperia. 1996. Phosphorylation by protein kinase $\mathrm{C}$ of serine-23 of the $\alpha-1$ subunit of rat $\mathrm{Na}^{+}, \mathrm{K}^{+}$-ATPase affects its conformational equilibrium. Proc. Natl. Acad. Sci. USA. 93:9132-9137.

14. Feschenko, M.S., and K.J. Sweadner. 1994. Conformation-dependent phosphorylation of $\mathrm{Na}^{+}, \mathrm{K}^{+}$-ATPase by protein kinase A and protein kinase C. J. Biol. Chem. 269:30436-30444.

15. Bartfai, T. 1979. Preparation of metal-chelate complexes and the design of steady-state kinetic experiments involving metal nucleotide complexes. $A d v$. Cyclic Nucleotide Res. 10:219-242.

16. Picciotto, M.R., J.A. Cohn, G. Bertuzzi, P. Greengard, and A.C. Nairn. 1992. Phosphorylation of the cystic fibrosis transmembrane conductance regulator. J. Biol. Chem. 267:12742-12752.

17. Bradford, M.M. 1976. A rapid and sensitive method for the quantitation of microgram quantities of protein utilizing the principle of protein binding. Anal. Biochem. 72:248-254.

18. Fisone, G., S.X.-J. Cheng, A.C. Nairn, A.J. Czernik, H.C. Hemmings, Jr., J.O. Höög, A.M. Bertorello, R. Kaiser, T. Bergman, H. Jörnvall, et al. 1994. Identification of the phosphorylation site for cAMP-dependent protein kinase on $\mathrm{Na}^{+}, \mathrm{K}^{+}$-ATPase and effects of site-directed mutagenesis. J. Biol. Chem. 269: 9368-9373.

19. Sanger, F., S. Nicklen, and A.R. Coulson. 1979. DNA sequencing with chain-terminating inhibitors. Proc. Natl. Acad. Sci. USA. 79:5463-5467.

20. Aizman, R.I., G. Celsi, L. Grahnquist, Z.M. Wang, Y. Finkel, and A. Aperia. 1996. Ontogeny of $\mathrm{K}^{+}$transport in rat distal colon. Am. J. Physiol. 271: G268-G274.

21. Toullec, D., P. Pianetti, H. Coste, P. Bellevergue, T. Grand-Perret, M. Ajakane, V. Baudet, P. Boissin, E. Bousier, F. Loriollet, et al. 1991. The bisindolylmaleimide GF $109203 x$ is a potent and selective inhibitor of protein kinase C. J. Biol. Chem. 266:15771-15781.

22. Wilkinson, S.E., J.E. Parker, and J.S. Nixon. 1993. Isoenzyme specificity of bisindolylmaleimides, selective inhibitors of protein kinase C. Biochem. J. 294:335-337.

23. Feschenko, M.S., and K.J. Sweadner. 1995. Structural basis for speciesspecific differences in the phosphorylation of $\mathrm{Na}, \mathrm{K}$-ATPase by protein kinase C. J. Biol. Chem. 270:14072-14077.

24. Newton, A. 1995. Protein kinase C: structure, function and regulation. J. Biol. Chem. 270:28495-28498.

25. Meves, H. 1994. Modulation of ion channels by arachidonic acid. Prog. Neurobiol. (Oxf.). 43:175-186.

26. Chen, S.G., and K. Murakami. 1992. Synergistic activation of type III protein kinase $\mathrm{C}$ by cis-fatty acid and diacylglycerol. Biochem. J. 282:33-39.

27. Shinomura, T., Y. Asaoka, M. Oka, K. Yoshida, and Y. Nishizuka. 1991. Synergistic action of diacylglycerol and unsaturated fatty acid for protein kinase C activation: its possible implications. Proc. Natl. Acad. Sci. USA. 88:51495153.

28. Nishizuka, Y. 1995. Protein kinase C and lipid signaling for sustained cellular responses. FASEB J. 9:484-496.

29. Sekiguchi, K., T. Masanori, K. Ogita, U. Kikkawa, and Y. Nishizuka. 1987. Three distinct forms of rat brain protein kinase C: differential response to unsaturated fatty acids. Biochem. Biophys. Res. Commun. 145:797-802.

30. Blobe, G.C., W.A. Khan, and Y.A. Hannun. 1995. Protein kinase C: cellular target of second messenger arachidonic acid? Prostaglandins, Leuko. Es- 
sent. Fatty Acids. 52(2-3):129-135.

31. Fisone, G., G.L. Snyder, J. Fryckstedt, M.J. Caplan, A. Aperia, and P. Greengard. 1995. $\mathrm{Na}+, \mathrm{K}(+)$-ATPase in the choroid plexus. Regulation by serotonin/protein kinase C pathway. J. Biol. Chem. 270:2427-2430.

32. Féraille, E., M.L. Carranza, B. Buffin-Meyer, M. Rousselot, A. Doucet, and H. Favre. 1995. Protein kinase C-dependent stimulation of $\mathrm{Na}^{+}, \mathrm{K}^{+}$-ATPase in rat proximal convoluted tubules. Am. J. Physiol. 268:C1277-C1283.

33. Speziale, N.B., E.H.S. Speziale, A. Terragno, and N.A. Terragno. 1982. Phospholipase-C activity in rat kidney. Effect of deoxycholate on phosphatidylinositol turnover. Biochim. Biophys. Acta. 712:65-70.

34. Östlund, E., C.F. Mendez, G. Jacobsson, J. Fryckstedt, B. Meister, and A. Aperia. 1995. Expression of protein kinase $\mathrm{C}$ isoforms in renal tissue. Kidney Int. 47:766-773.

35. Endou, H. 1983. Distribution and some characteristics of cytochrome P-450 in the kidney. J. Toxicol. Sci. 8:165-176.

36. Sultana, C., Y. Shen, V. Rattan, and V.K. Kalra. 1996. Lipoxygenase metabolites induced expression of adhesion molecules and transendothelial migration of monocyte-like HL-60 cells is linked to protein kinase C activation. $J$. Cell Physiol. 167:477-487.

37. Honn, K.V., J. Timar, J. Rozhin, R. Bazaz, M. Sameni, G. Ziegler, and B.F. Sloane. 1994. A lipoxygenase metabolite, 12-(S)-HETE, stimulates protein kinase C-mediated release of cathepsin B from malignant cells. Exp. Cell Res. 214:120-130.

38. Hack, N., A. Schultz, P. Clayman, H. Goldberg, and K.L. Skorecki 1995. Transmembrane signalling in kidney: health and disease. Pediatr. Nephrol. 9:514-525.

39. Zou, A.P., J.D. Imig, P.R. Ortiz de Montellano, Z. Sui, J.R. Falck, and R.J. Roman. 1994. Effect of P-450 $\omega$-hydroxylase metabolites of arachidonic acid on tubuloglomerular feedback. Am. J. Physiol. 266:F934-F941.

40. Wang, W., M. Lu., and S.C. Herbert. 1996. Cytochrome P-450 metabolites mediate extracellular $\mathrm{Ca}^{2+}$-induced inhibition of apical $\mathrm{K}^{+}$channels in the TAL. Am. J. Physiol. 271:C103-C111. 